\title{
Quality characteristics of high-acidity vinegar prepared with grape juice
}

\author{
Seung-Mi Woo ${ }^{1}$, Soo-Hwan $\mathrm{Yeo}^{2}$, Joong-Ho Kwon ${ }^{3}$, Sun-Hwa Kim ${ }^{1}$, Yong-Jin Jeong ${ }^{*}$ \\ ${ }^{1}$ Department of Food Science and Technology, Keimyung University, Daegu 704-701, Korea \\ ${ }^{2}$ Fermented Food Science Division, Department of Agrofood Resources, RDA, Wanju 565-850, Korea \\ ${ }^{3}$ Department of Food Science and Technology, Kyungpook National University, Daegu 702-701, Korea
}

\section{포도과즙을 이용하여 제조한 고산도 식초의 품질특성}

\author{
우승미 $^{1} \cdot$ 여수환 $^{2} \cdot$ 권중호 $^{3} \cdot$ 김선화 $^{1} \cdot$ 정용진 $^{1 *}$ \\ ${ }^{1}$ 계명대학교 식품가공학과, ${ }^{2}$ 농촌진흥청 국립농업과학원 농식품자원부 발효식품과, \\ 3 경북대학교 식품공학과
}

\begin{abstract}
This study was conducted to develop a high-acidity vinegar production (over TA $10 \%$ ) technology using grape juice to reduce the importation of high-acidity vinegar. The manufacturing condition's effect on the quality of high-acidity vinegar using pure grape juice without the addition of other nutrients for fermentation was investigated. Twelve percent acidity in vinegar was obtained from grape wine with $6 \%$ alcohol content. The acetic-acid yield from grape wine decreased when the wine's initial alcohol content was high, which extended the induction time. The pH value was similar in all the treatment groups. The sugar content of the 1st-stage fermentation (1st AAF) was proportional to the initial alcohol content whereas in the 2nd-stage fermentation (2nd AAF), the sugar content was highest in the $6 \%$-alcohol treatment. The major organic acids of the high-acidity grape vinegar included tartaric acid, malic acid, and citric acid. The acid content of the high-acidity initial alcohol group was higher than that of the low-acidity initial alcohol group due to the alcohol content added by the fed-batch and acetic-acid yield difference. The ethyl alcohol content was 364 6,091 ppm (the main alcohol while the others had only traces in all the groups). In conclusion, it was possible to manufacture $12 \%$ high-acidity vinegar without the addition of an external nutrient source to grape wine containing $6 \%$ initial alcohol content. Finally, a complementary study will be required to shorten the fermentation period through the fed-batch-style addition of alcohol for the purpose of industrialization.
\end{abstract}

Key words : grape juice, vinegar, titratable acidity, organic acid

\section{서 론}

포도(Vitis vinifera L.)는 갈대나무목(Rhamnale) 포도과 (Vitaceae) 작물로 전세계적으로 가장 많이 재배되는 과수 중의 하나이다(1,2). 포도 원산지는 북반구의 온대나 아열

*Corresponding author. E-mail : yjjeong@kmu.ac.kr Phone : 82-53-580-5557, Fax : 82-53-580-5557

Received 29 September 2014; Revised 7 January 2015; Accepted 16 January 2015.

Copyright (c) The Korean Society of Food Preservation. All rights reserved.
대지방이고 품종은 8,500여 종이며, 양조용으로 인기 있고 널리 알려진 것은 50 여 종으로 보고되고 있다(3). 이들 포도 품종들은 용도에 따라서 생식용, 건포도용, 포도주 및 기타 가공품용으로 크게 구분되며, 국내 전체 생산량의 $70 \%$ 이 상이 생식으로 소비되고 그 외 와인, 음료, 쨈, 식초 등 가공 식품의 원료로 이용되고 있다(2). 포도는 알칼리성 과일로 미네랄, 전화당, 주석산, 구연산, 칼륨, 철분, 비타민 $\mathrm{A}, \mathrm{B}_{1}$, $\mathrm{B}_{2}, \mathrm{D}$ 등과 다양한 phytochemical을 풍부하게 함유하고 있 어서 피로회복, 피부미용, 소화개선, 식욕증진과 같은 생리 활성 증진효과를 나타내며 $(4,5)$, 심혈관질환이나 항암활성 이 우수하고 면역 조절 활성을 가진다고 많이 보고되고 
있다(6-8). 이러한 효능을 나타내는 생리활성물질 중 대표 적인 물질로 resveratrol이 있으며, 이외에도 phenolic acid, catechin, flavonoid, proanthocyanidin 등이 다양하게 존재한 다(9). 식초는 식품의 맛을 돋워주는 산미료로서, 발효과정 에서 생성된 독특한 방향과 신맛을 가지는 대표적인 발효식 품이다(10). 특히 포도를 원료로 제조된 발사믹 식초는 이탈 리아 중부 모데나 지방 특산물로서 옛날에는 약으로도 사용 했으며 그 향과 맛이 매우 특이하여 조리용 식초로 많이 사용되고 있다(11). 국내 식초 생산은 2009년도 기준으로 주정식초 $38.9 \%$, 과일식초 $32.5 \%$, 곡물식초 $21.4 \%$, 합성식 초 $7.0 \%$, 기타 $6 \%$ 로 나타났으나 건강에 대한 소비자 인식이 높아지면서 매년 과일 및 곡물 천연 발효식초에 대한 소비 가 증가하고 있는 추세이다(12). 식초 산도의 분류에 따라 $4 \sim 5 \%$ 의 저산도, $6 \sim 7 \%$ 의 일반산도, $12 \sim 14 \%$ 의 2 배 산도 및 18 19\% 3배 식초로 나눌 수 있으며 고산도 식초(적정산 도 $10 \%$ 이상)의 경우 이미.이취 개선 및 식초를 대량으로 사용하는 공장이나 요식업소에서 운송비와 저장 공간 절감 등의 이점을 가지고 있어 많이 소비되고 있다(13). 현재 국내에서 시판되고 있는 고산도 과일식초는 알코올 발효를 거치지 않고 주정과 영양원을 이용하여 초산 발효만 시킨 후 약 $30 \%$ 의 과즙을 첨가하여 생산되고 있으며 대부분 국외에서 설비 및 초산균주를 수입하여 제조하고 있어 대체 기술의 개발이 요구된다(13). 국내의 고산도 식초에 관한 연구는 고농도 에탄올 내성 초산균 및 양조식초로 부터 고산도 초산균 분리 $(14,15)$, 영양원을 넣은 합성배지에 유 가식 배양을 통한 two stage 고산도 식초 제조(16), 온도 조절을 통한 single stage 고산도 식초 제조(17) 등이 활발히 진행 중이나 $100 \%$ 과즙을 이용한 천연 고산도 식초 제조에 관한 국내 연구는 미비한 실정이다.

따라서 본 연구에서는 포도를 활용하고 수입에 의존하고 있는 고산도 식초 생산기술을 대체하고자 일체의 영양원을 사용하지 않고 순수 포도과즙으로 2 단계 발효에 의한 고산 도 식초 제조 조건을 조사하고자 하였다.

\section{재료 및 방법}

\section{실험재료 및 사용균주}

본 연구에 사용된 포도 농축액 $\left(72^{\circ} \mathrm{Brix}\right)$ 은 (주)롯데쇼핑 식품사업본부에서 제공받아 냉장 보관하여 실험에 사용하 였다. 선행연구(18)에서 발효성이 우수한 알코올발효 효모 Saccharomyces cerevisiae Fermivin(DSM Food Specialties, Seclin, France)은 와인킷 코리아(Wine Kit Korea Co., LTD., Seoul, Korea)에서 구입하였다. 초산균은 Acetobacter pomorum $\mathrm{KJY} 8(\mathrm{KCTC} 10173 \mathrm{BP})$ 을 고체배지에서 $30^{\circ} \mathrm{C}, 48$ 시간 계대 배양한 후 $4^{\circ} \mathrm{C}$ 에서 냉장보관하면서 사용하였다.
주모 및 종초

주모는 포도농축액을 $10^{\circ} \mathrm{Brix}$ 로 희석하여 $121^{\circ} \mathrm{C}$ 에서 15 분간 살균시킨 다음 효모 $0.02 \%(\mathrm{w} / \mathrm{v})$ 를 접종하여 항온배양 기(HB-103-2H, Hanbaek Scientific Co., Bucheon, Korea)에 서 $30^{\circ} \mathrm{C}, 24$ 시간동안 정치배양 시켜 원료량의 $5 \%(\mathrm{v} / \mathrm{v})$ 를 사용하였고, 초산발효에 사용된 종초는 포도 알코올 발효 액을 알코올 함량 $5 \%$ 로 희석한 후 $A$ pomorum KJY 8 을 접종하여 $30^{\circ} \mathrm{C}$ 에서 $250 \mathrm{rpm}$ 으로 교반하여 5 일간 배양시켜 원료량의 $10 \%(\mathrm{v} / \mathrm{v})$ 를 사용하였다.

\section{포도 알코올 발효액 제조}

1 단계 초산발효에 사용된 알코올 발효액은 $20^{\circ} \mathrm{Brix}$ 로 희석한 포도 농축액에 주모를 $5 \%(\mathrm{v} / \mathrm{v})$ 접종하여 항온배양기 (HB-103-2H, Hanbaek Scientific Co., Bucheon, Korea)에서 $30^{\circ} \mathrm{C}, 5$ 일 동안 정치배양 시켰으며, 고산도 포도식초 제조를 위한 유가식 첨가용 알코올 발효액은 $30^{\circ} \mathrm{Brix}$ 로 희석한 포 도 농축액에 주모를 $5 \%(\mathrm{v} / \mathrm{v})$ 접종하여 상기와 같은 방법으 로 정치배양 시켜 발효 종료 후 $10,000 \mathrm{rpm}$ 으로 5 분 동안 원심분리 시킨 상등액에 주정을 사용하여 알코올 함량 $20 \%$ 가 되도록 보정하여 사용하였다.

\section{고산도 포도식초 제조}

전보(19)와 같은 방법으로 2 단계 발효에 의한 고산도 포 도식초를 제조하였다. 1 단계 초산발효는 포도 알코올 발효 액의 알코올 농도를 각각 $6,7,8$ 및 $9 \%$ 로 희석한 후 종초를 $10 \%(\mathrm{v} / \mathrm{v})$ 접종하여 Jar-fermentor(KF-5 L, Kobiotech Co., Seoul, Korea)에서 $30^{\circ} \mathrm{C}, 500 \mathrm{rpm}$, 공기 투입량 $0.5 \mathrm{~L} / \mathrm{min}$ 로 실시하였다. 2 단계 초산발효는 1 단계 초산발효액의 적정산 도가 6시간 동안 변화가 없는 시점부터 고농도 알코올 발효 액을 유가식으로 첨가하면서 적정산도가 $12 \%$ 에 도달하는 시점까지 진행되었으며 이때 첨가량은 1 단계 발효액 대비 계산 수치적으로 알코올 함량 $0.2 \%$ 가 첨가되도록 일정한 속도로 주입하였다. 발효단계에 따른 품질특성은 알코올발 효액(W), 초기 초산발효액(IAAF), 1 단계 초산발효액(1st $\mathrm{AAF}), 2$ 단계 초산발효액(2nd AAF)으로 구분하여 분석하 였다.

\section{당도 및 알코올 함량}

당도는 digital refractometer(PR-101, Atago Co., LTD., Tokyo, Japan)를 사용하여 측정하였다. 알코올 함량은 시료 $100 \mathrm{~mL}$ 을 증류한 다음 주정계를 이용하여 측정한 값을 Gay Lussac table로 환산하여 산출하였다.

\section{적정산도 및 $\mathrm{pH}$}

적정산도는 시료 $1 \mathrm{~mL}$ 에 $1 \%$ phenolphthalein 지시약을 2 3방울 떨어뜨린 다음 $0.1 \mathrm{~N} \mathrm{NaOH}$ 로 중화 적정하여 포도 농축액 및 당도에 따른 알코올 발효액은 tartaric acid로 환산 
하였고, 고산도 초산발효과정 중 발효단계별 알코올 및 초 산발효액은 acetic $\mathrm{acid}(\%)$ 로 환산하였다. $\mathrm{pH}$ 는 $\mathrm{pH}$ meter(Metrohm 691, Metrohm UK Ltd., Herisau, Switzerland) 로 실온에서 측정하였다.

\section{발효수율}

초산 발효수율은 총 알코올 농도에 따른 이론적인 초산 생산량에 대한 초산 생성량을 백분율로 나타내었다.

$$
\text { 초산 발효수율 }=\frac{\text { 최종산도(\%, } \mathrm{w} / \mathrm{v}) \text {-초기산도(\%, w/v) }}{\text { 총 알코을 농도(\%, } \mathrm{v} / \mathrm{v}) \times 1.304} \times 100
$$

색도

색도는 UV-visible spectrophotometer(UV-1601, Shimazu Co., Kyoto, Japan)를 이용하여 Hunter scale에 의한 명도 (L), 적색도 (a) 및 황색도 (b)로 나타내었으며, 이때 대조구 는 증류수 $(\mathrm{L}=100.00, \mathrm{a}=0.02, \mathrm{~b}=-0.10)$ 를 사용하였다.

\section{유기산 함량}

유기산은 시료를 Sep-pak $\mathrm{C}_{18}$ cartridge에 통과시킨 다음, $0.45 \mu \mathrm{m}$ membrane filter로 여과하여 high performance liquid chromatography(Waters 1515, Waters Co., Ltd., Milford, MA, USA)로 분석하였다(19). 유기산 분석 column은 Atlantis ${ }^{\mathrm{TM}} \mathrm{dC}_{18}(3.9 \times 150 \mathrm{~mm}$, Waters Co.), mobile phase는 $20 \mathrm{mM} \mathrm{NaH} \mathrm{PO}_{4}(\mathrm{pH}$ 2.7)를 사용하였고 flow rate는 1.0 $\mathrm{mL} / \mathrm{min}$, injection volume은 $20 \mu \mathrm{L}$, detector는 UV(Waters $2487,210 \mathrm{~nm}$ )를 사용하였다.

\section{미량 알코올 성분}

미량 알코올은 초산 발효액을 membrane filter(pore size $0.45 \mu \mathrm{m}$, Advantec MFS, Japan)로 여과한 후, 여과액을 gas chromatography(Hewlett packard 5980, Palo Alto, CA, USA) 를 이용하여 분석하였다. 분석 column은 HP-INNOWAX capillary column $(30 \mathrm{~m} \times 0.25 \mathrm{~mm} \times 0.5 \mu \mathrm{m}$, Agilent, MA, USA) 를 사용하였고, oven의 온도프로그램은 $40^{\circ} \mathrm{C}$ 에서 2 분간 유 지한 다음 분당 $2^{\circ} \mathrm{C}$ 씩 $130^{\circ} \mathrm{C}$ 까지 승온시킨 후 1 분간 머물렀 다. Injection 및 detector 온도는 각각 250 및 $260^{\circ} \mathrm{C}$, split ratio는 10:1, flow rate는 $1.0 \mathrm{~mL} / \mathrm{min}$, carrier gas는 $\mathrm{N}_{2}$, detector는 flame ionization detector(FID)를 사용하였다.

\section{통계처리}

모든 실험은 3 회 반복하여 측정한 평균과 표준편차로 나타내었으며 각 실험결과에 대한 통계분석은 $\operatorname{SPSS}(18.0$, SPSS Inc., Chicago, IL, USA) 통계 프로그램을 이용하였다 ( $p<0.05)$. 수준에서 일원배치 분산분석법을 시행하고 Duncan's multiple range test로 각 실험군의 평균치 간의 유의적 차이를 검증하였다.

\section{결과 및 고찰}

\section{포도 농축액 및 알코올 발효액의 품질특성}

포도 함량이 높은 고산도 식초를 제조하기 위하여 포도 농축액을 20 및 $30^{\circ} \mathrm{Brix}$ 로 각각 희석하여 주모를 $5 \%(\mathrm{v} / \mathrm{v})$ 접종한 후 알코올 발효시킨 발효액 및 포도농축액 $\left(20^{\circ} \mathrm{Brix}\right)$ 의 품질특성을 분석한 결과는 Table 1 과 같다. $20^{\circ} \mathrm{Brix}$ 로 희석한 포도농축액은 적정산도 $0.7 \%, \mathrm{pH} 3.9$ 였으며 Park 등(20)의 국내재배 Campbell's Early 포도 품종의 적포도주 제조 적합성에서 일반적으로 발효 전 포도즙의 적정산도는 $0.6 \sim 0.8 \%$ 가 적당하고 $\mathrm{pH}$ 는 3.2 3.6이 적당하다고 보고되 어 적정산도는 일치하였으나 $\mathrm{pH}$ 는 본 연구와 다소 차이가 있었다. 유리당은 fructose $8,582 \mathrm{mg} \%$, glucose $7,749 \mathrm{mg} \%$, sucrose 및 maltose는 불검출로 나타났다(data not shown). 알코올발효액의 당도는 초기당도 $20^{\circ} \mathrm{Brix}$ 구간은 $64^{\circ} \mathrm{Brix}$, $30^{\circ} \mathrm{Brix}$ 구간은 $12.6^{\circ} \mathrm{Brix}$ 로 낮아졌고 알코올 함량은 당도 와 반비례하여 $20^{\circ} \mathrm{Brix}$ 구간이 $10.8 \%, 30^{\circ} \mathrm{Brix}$ 구간이 $16.6 \%$ 로 나타났다. 적정산도는 각각 0.9 및 $1.1 \%$ 였고, $\mathrm{pH}$ 는 각각 3.5 및 4.1로 나타났다. 이는 Moon 등(21)의 활성건조 효모를 이용한 포도주의 발효 특성에서 Saccharomyces uvarum Lalvin W15균주로 발효한 포도주의 적정산도가 $0.99 \%$ 로 나타나 유사한 결과를 보였으나 Saccharomyces cerevisiae Epernay 퓨균주로 발효한 포도주의 적정산도는 $0.74 \%$ 로 나타나 사용균주에 따라 포도주의 적정산도에 영 향을 미치는 것으로 나타났다. 또한 Iverson(22)의 와인 발 효 가이드에서 포도주 적정산도는 $0.60 \sim 0.65 \%$ 가 적당하 고 $\mathrm{pH}$ 는 $3.2 \sim 3.3$ 가 되어야한다는 내용과 비교해 볼 때 다소 높은 편이나 연속적으로 초산발효가 진행되기 때문에 잡균 오염에 대한 가능성은 없을 것으로 판단된다.

상기 결과에 준하여 1 단계 초산발효는 초기당도 $20^{\circ} \mathrm{Brix}$ 포도 농축액으로 알코올 발효를 실시하여 각 알코올 함량을 $6,7,8$ 및 $9 \%$ 로 희석하여 사용하였으며 2단계 초산발효에 사용된 유가액은 $30^{\circ} \mathrm{Brix}$ 포도 농축액으로 알코올 발효한 후 주정으로 알코올 함량 $20 \%$ 로 보정한 후 사용하였다.

Table 1. Comparison of physicochemical properties of grape concentration and grape alcohol fermentation for vinegar fermentation

\begin{tabular}{cccc}
\hline & \multirow{2}{*}{$\begin{array}{c}\text { Grape concentration } \\
\left(20^{\circ} \text { Brix }\right)\end{array}$} & \multicolumn{2}{c}{ Initial sugar content $\left({ }^{\circ}\right.$ Brix $)$} \\
\cline { 3 - 4 } & $20.0 \pm 0.0^{1)}$ & $6.4 \pm 0.0$ & $12.6 \pm 0.0$ \\
\hline Sugar content ( ${ }^{\circ}$ Brix $)$ & $\mathrm{ND}$ & $10.8 \pm 0.1$ & $16.6 \pm 0.1$ \\
Alcohol content (\%) & $0.7 \pm 0.0$ & $0.9 \pm 0.1$ & $1.1 \pm 0.0$ \\
Titratable acidity (\%) & $3.9 \pm 0.0$ & $3.5 \pm 0.0$ & $4.1 \pm 0.0$ \\
$\mathrm{pH}$ & &
\end{tabular}

${ }^{1)}$ Values are means \pm SD $(\mathrm{n}=3)$. 


\section{2단계 고산도 초산발효}

적정산도 및 초산 발효수율

초기 알코올 함량(6, 7, 8 및 9\%)에 따른 고산도 초산발효 의 단계별 품질특성 중 적정산도 변화 및 초산 발효수율을 조사한 결과는 Fig. 1 및 Table 2와 같다. 1 단계 초산발효기 간 동안 적정산도는 꾸준히 증가하여 1단계 초산발효(1st $\mathrm{AAF})$ 에서 초기 알코올 $6 \%$ 첨가구는 $6.0 \%$, 초기 알코올 $7,8 \%$ 첨가구는 각각 $6.4 \%$ 및 $7.4 \%$, 초기 알코올 $9 \%$ 첨가구 는 $5.4 \%$ 로 나타났다. 초산변환수율은 각각 $63.9,59.2,61.3$ 및 $37.5 \%$ 로, 초기 알코올 $6 \%$ 첨가구에서 가장 높았으며 9\% 첨가구에서는 발효가 저해되는 것으로 생각된다. $\mathrm{Kim}$ 등(23)은 매실을 이용한 식초를 발효할 때 알코올 $6 \%$ 첨가 구에서 배양 7 일째 $6.5 \%$ 로서 가장 높은 산도를 나타내었으 며, 8 및 10\% 첨가구에서는 산도가 오히려 낮게 나타나 초기알코올 농도가 $6 \%$ 일 때 초산발효가 가장 효과적으로 진행되며, 적정농도 범위를 벗어나면 정상적인 발효가 유 도되지 않는다고 보고한 것과 유사한 경향을 나타내어 1차 발효의 알코올 농도를 $6 \sim 8 \%$ 로 설정하여 2단계 초산발효 를 진행하였다. 2단계 초산발효(2nd AAF) 단계에서 초기

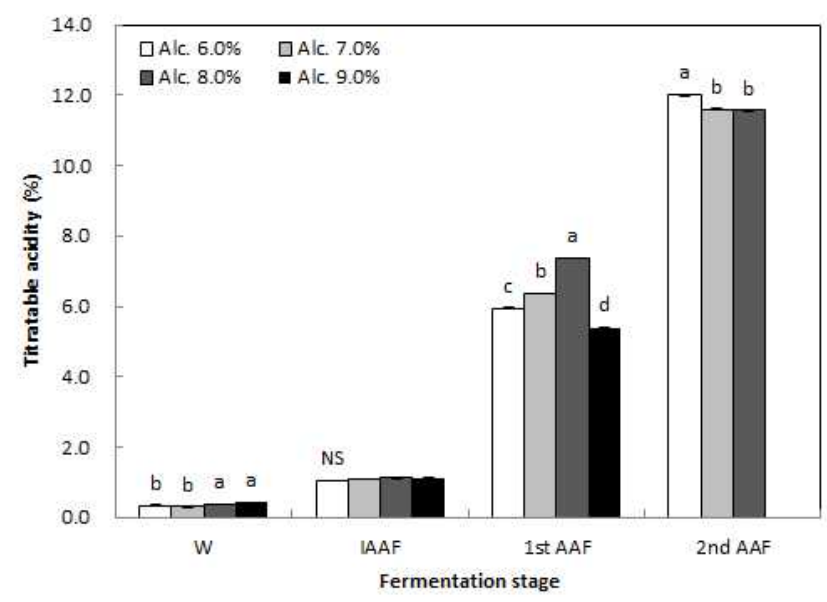

Fig. 1. Changes in titratable acidity of grape vinegar fermentation by initial alcohol content and fermentation stage.

$\mathrm{W}$, grape wine; IAAF, initial acetic acid fermentation broth; 1st AAF, 1st stage acetic acid fermentation broth; 2nd AAF, 2nd stage acetic acid fermentation broth. Values are means $\pm \mathrm{SD}(\mathrm{n}=3)$. Means with different letters $(\mathrm{a}-\mathrm{d})$ above the bars of each fermentation day are significantly different $(\mathrm{p}<0.05)$ by Duncan's multiple range test. NS, not significantly different.

Table 2. Effect of initial alcohol content on the grape vinegar production yield

\begin{tabular}{ccccc}
\hline & \multicolumn{4}{c}{ Initial alcohol content (\%) } \\
\cline { 2 - 5 } & 6 & 7 & 8 & 9 \\
\hline $\begin{array}{c}\text { Acetic acid } \\
\text { fermentation } \\
\text { yield (\%) }\end{array}$ & $70.3 \pm 0.1^{1) 22)}$ & $67.7 \pm 0.0^{\mathrm{b}}$ & $67.5 \pm 0.0^{\mathrm{b}}$ & - \\
\hline
\end{tabular}

${ }^{1)}$ Values are means $\pm \mathrm{SD} \quad(\mathrm{n}=3)$.

${ }^{2)}$ Means with different superscripts (a-c) in the same row are significantly different $(\mathrm{p}<0.05)$ by Duncan's multiple range test.
알코올 6,7 및 $8 \%$ 첨가구는 꾸준히 증가하여 각각 적정산 도 $12,11.59$ 및 $11.57 \%$ 까지 도달하였다. 초기 알코올 $9 \%$ 첨가구는 IAAF부터 정상발효가 진행되지 못했기 때문에 2단계 초산발효도 비정상적으로 진행될 것으로 판단되어 실험구간에서 제외시켰다. 고산도 포도식초의 초산수율은 초기 알코올 $6 \%$ 첨가구가 $70.3 \%$ 로 가장 높았고 초기 알코 올 7 및 $8 \%$ 첨가구는 약 $67 \%$ 로 나타났으며, 전보(19)의 고산도 사과식초 제조에서 초기 알코올 $6 \%$ 첨가구가 초산 수율 $70.3 \%$ 로 가장 높게 나타났다는 결과와 일치하였다. 따라서 본 연구의 고산도 포도식초에서는 초기 알코올 함량 $6 \%$ 로 설정하는 것이 적당할 것으로 판단된다.

\section{$\mathrm{pH}$ 및 당도}

초기 알코올 함량(6, 7, 8 및 9\%)에 따른 고산도 초산발효 의 단계별 품질특성 중 $\mathrm{pH}$ 및 당도의 변화를 조사한 결과는 Fig. 2 및 3 과 같다. $\mathrm{pH}$ 는 알코올 발효기간 동안에는 큰 변화가 없었으나 $1 \mathrm{st} \mathrm{AAF}$ 이후부터 조금씩 감소하였고 초 기 알코올 함량에 따른 $\mathrm{pH}$ 는 비슷한 수치를 나타내었다. 시판 과실식초의 이화학적 품질특성을 조사한 Kim 등(24) 은 사과식초의 $\mathrm{pH}$ 가 2.75 3.30, 배식초의 $\mathrm{pH}$ 가 3.49 3.77, 포도식초의 $\mathrm{pH}$ 가 2.69 2.97로 나타나 산미가 높은 포도가 다른 과일에 비하여 전체적으로 $\mathrm{pH}$ 가 낮았으며 본 연구의 포도식초와 비슷한 수치를 나타내었다. 당도는 발효기간 중 $1 \mathrm{st} \mathrm{AAF까지는} \mathrm{큰} \mathrm{변화가} \mathrm{없었으나} \mathrm{그} \mathrm{후} \mathrm{급격히} \mathrm{증가하}$ 였다. 또한 알코올발효(W)에서 1st $\mathrm{AAF}$ 까지 초기 알코올 함량이 높을수록 높게 나타났으며 2nd AAF기간 동안에는 초기 알코올 $6 \%$ 첨가구에서 가장 증가율이 높았다. 이는 초기 알코올 함량이 낮을수록 유가식 배양을 통해 첨가된 알코올 발효액의 첨가량이 많기 때문에 당 증가율에 영향을

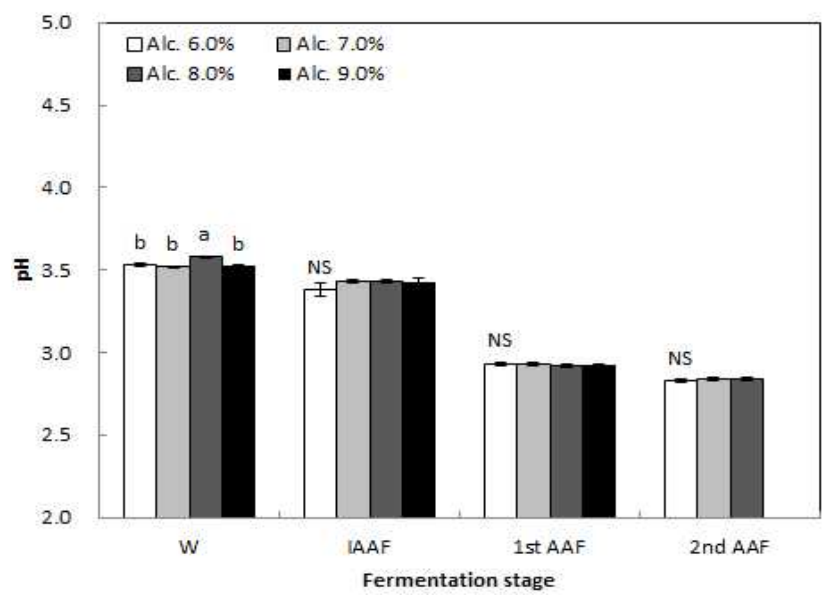

Fig. 2. Changes in $\mathrm{pH}$ of grape vinegar fermentation by initial alcohol content and fermentation stage.

$\mathrm{W}$, grape wine; IAAF, initial acetic acid fermentation broth; 1st AAF, 1st stage acetic acid fermentation broth; 2nd AAF, 2nd stage acetic acid fermentation broth. Values are means $\pm S D(n=3)$. Means with different letters $(a-b)$ above the bars of each fermentation day are significantly different $(\mathrm{p}<0.05)$ by Duncan's multiple range test. NS, not significantly different. 
준 것으로 생각되며, 전보(19)의 고산도 사과식초 제조과정 중 2 단계 초산발효에서 당도가 급격히 증가하였다는 결과 와도 일치하였다.

\section{색도}

초기 알코올 함량(6, 7, 8 및 9\%)에 따른 고산도 초산발효 의 단계별 품질특성 중 색도의 변화를 조사한 결과는 Table 3 과 같다. 명도(L)는 발효기간 중 $\mathrm{W}$ 에서 $30 \sim 37,1 \mathrm{st} \mathrm{AAF}$ 에 서 37 47로 증가하였으나 2nd AAF에서는 23 27로 급격 히 감소하였다. 초기 알코올 함량에 따른 영향에서도 $\mathrm{W}$ 에 서 1st $\mathrm{AAF}$ 까지는 초기 알코올 함량이 높을수록 명도가 감소하였으나 2nd $\mathrm{AAF}$ 에서는 반대의 경향으로 나타났다. 이는 초기 알코올 함량이 낮을수록 유가식 배양을 통해 첨가된 알코올 발효액의 첨가량이 많으며 유가식 배양액의 명도가 낮기 때문인 것으로 판단되었다. 적색도(a)는 종초 를 첨가하는 초기 초산발효(IAAF)구간을 제외하고는 꾸준 히 증가하였고, 황색도(b)는 명도와 같은 경향이었다. 초기 알코올 함량에 따른 적색도 및 황색도는 큰 차이가 없었다. 적포도주의 발효 특성을 조사한 $\mathrm{Kim}$ 등(25)은 Muscat Bailey A 품종의 명도가 14.70 17.27, 적색도가 40.28 43.53 , 황색도가 21.45 24.93으로 나타났고, Bae 등(26)은 적포도주 명도가 20.04 19.14, 적색도가 42.45 49.15, 황 색도가 12.57 15.60으로 나타나 본 연구의 $\mathrm{W}$ 구간과 비교 해 볼 때 적색도의 수치가 비슷하게 나타났으며, 포도 농축 액은 과피의 안토시안 함량이 높아 다른 과일에 비하여 적색도 수치가 높았다.

Table 3. Changes in color of the grape vinegar fermentation by initial alcohol content and fermentation stage

\begin{tabular}{|c|c|c|c|c|c|c|}
\hline & & \multirow{2}{*}{$\begin{array}{l}\text { Initial alcohol } \\
\text { content (\%) }\end{array}$} & \multicolumn{4}{|c|}{ Fermentation stage ${ }^{1)}$} \\
\hline & & & W & IAAF & 1st AAF & 2nd AAF \\
\hline \multirow{12}{*}{ Color } & \multirow{4}{*}{$\mathrm{L}$} & 6 & $36.7 \pm 0.1^{2 \mathrm{a} a 3)}$ & $37.4 \pm 0.1^{\mathrm{b}}$ & $47.5 \pm 0.0^{\mathrm{a}}$ & $23.2 \pm 0.2^{c}$ \\
\hline & & 7 & $33.1 \pm 0.1^{\mathrm{b}}$ & $38.6 \pm 0.2^{\mathrm{a}}$ & $43.8 \pm 0.2^{b}$ & $25.9 \pm 0.1^{\mathrm{b}}$ \\
\hline & & 8 & $30.2 \pm 0.0^{\mathrm{d}}$ & $31.1 \pm 0.1^{\mathrm{d}}$ & $37.2 \pm 0.1^{\mathrm{d}}$ & $27.2 \pm 0.2^{\mathrm{a}}$ \\
\hline & & 9 & $30.6 \pm 0.1^{\mathrm{c}}$ & $32.9 \pm 0.1^{\mathrm{c}}$ & $38.1 \pm 0.0^{c}$ & - \\
\hline & \multirow{4}{*}{$\mathrm{a}$} & 6 & $42.2 \pm 0.2^{\mathrm{d}}$ & $40.4 \pm 0.0^{c}$ & $44.1 \pm 0.0^{c}$ & $45.0 \pm 0.0^{\mathrm{c}}$ \\
\hline & & 7 & $44.3 \pm 0.1^{\mathrm{b}}$ & $40.3 \pm 0.2^{c}$ & $48.0 \pm 0.0^{\mathrm{b}}$ & $48.1 \pm 0.1^{\mathrm{b}}$ \\
\hline & & 8 & $44.7 \pm 0.1^{\mathrm{a}}$ & $43.3 \pm 0.0^{b}$ & $49.9 \pm 0.0^{\mathrm{a}}$ & $49.8 \pm 0.0^{\mathrm{a}}$ \\
\hline & & 9 & $43.4 \pm 0.1^{c}$ & $44.8 \pm 0.0^{\mathrm{a}}$ & $49.9 \pm 0.0^{\mathrm{a}}$ & - \\
\hline & \multirow{4}{*}{$\mathrm{b}$} & 6 & $18.5 \pm 0.1^{\mathrm{a}}$ & $17.1 \pm 0.1^{\mathrm{NS}}$ & $20.9 \pm 0.0^{\mathrm{d}}$ & $15.5 \pm 0.0^{\mathrm{c}}$ \\
\hline & & 7 & $18.1 \pm 0.0^{b}$ & $17.7 \pm 0.0$ & $21.1 \pm 0.0^{\mathrm{c}}$ & $17.3 \pm 0.0^{\mathrm{b}}$ \\
\hline & & 8 & $17.4 \pm 0.1^{\mathrm{c}}$ & $17.4 \pm 0.0$ & $21.5 \pm 0.1^{\mathrm{b}}$ & $18.2 \pm 0.1^{\mathrm{a}}$ \\
\hline & & 9 & $17.1 \pm 0.0^{\mathrm{d}}$ & $17.3 \pm 0.0$ & $22.3 \pm 0.0^{\mathrm{a}}$ & - \\
\hline
\end{tabular}

${ }^{1)} \mathrm{W}$, grape wine; IAAF, initial acetic acid fermentation broth; 1st AAF, 1st stage acetic acid fermentation broth; 2nd AAF, 2nd stage acetic acid fermentation broth.

${ }^{2)}$ Values are means \pm SD $(\mathrm{n}=3)$.

${ }^{3)}$ Means with different superscripts (a-d) in the same column are significantly different $(p<0.05)$ by Duncan's multiple range test.

NS: not significantly different.

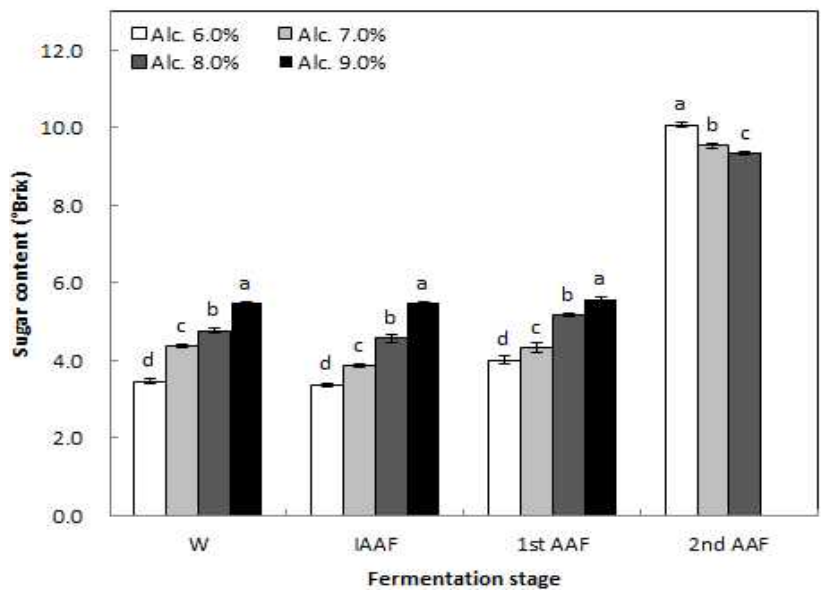

Fig. 3. Changes in sugar content of grape vinegar fermentation by initial alcohol content and fermentation stage.

W, grape wine; IAAF, initial acetic acid fermentation broth; 1st AAF, 1st stage acetic acid fermentation broth; 2nd AAF, 2nd stage acetic acid fermentation broth. Values are means $\pm \mathrm{SD}(\mathrm{n}=3)$. Means with different letters $(\mathrm{a}-\mathrm{d})$ above the bars of each fermentation day are significantly different $(p<0.05)$ by Duncan's multiple range test. NS: not significantly different.

\section{유기산 함량}

초기 알코올 함량 $(6,7,8$ 및 9\%)에 따른 고산도 초산발효 의 단계별 품질특성 중 유기산 함량 변화를 조사한 결과는 Table 4와 같다. 주요 유기산은 acetic acid, tartaric acid, malic acid 및 citric acid로 검출되었다. W단계에서는 초기 알코올 함량이 높아짐에 따라 유기산 함량이 높게 나타났으 나 2nd AFF에서는 유가식 첨가량 및 초산 발효수율 차이로 인하여 초기 알코올 함량이 낮을수록 높게 검출되었다. 특 히, acetic acid의 경우 $1 \mathrm{st} \mathrm{AFF}$ 에서는 초기 알코올 $9 \%$ 첨가 구만 4,837 $\mathrm{mg} \%$ 로 비정상 발효가 진행되어 $2 \mathrm{nd} \mathrm{AFF}$ 를 제외시켰다. $2 \mathrm{nd} \mathrm{AFF}$ 에서는 초기 알코올 6, 7 및 $8 \%$ 첨가구 모두 $10,000 \mathrm{mg} \%$ 이상 검출되었다. Oxalic acid는 모든 구간 에서 발효 단계가 진행될수록 높아지는 경향을 보였고 초기 알코올 함량에 따른 큰 차이는 없었다. 2 단계 발효에 의한 과실식초 품질특성을 조사한 Kwon 등(27)은 포도식초의 주요 유기산 성분으로 acetic acid, tartaric acid, citric acid 및 lactic acid를 보고하였으며 본 연구에서 불검출된 lactic $\mathrm{acid}$ 가 검출되어 다소 차이를 보였다. 이는 포도에서 이행된 유기산 함량, 원료 농축액의 희석방법 및 알코올·초산발효 과정에 따른 차이로 생각된다.

\section{미량 알코올 성분}

고산도 포도식초(초기 알코올 함량 6,7 및 $8 \%$ )의 미량 알코올 성분을 조사한 결과는 Table 5 와 같다. 포도식초의 주요 알코올 성분은 methyl alcohol, 2-methyl-1-propanol 및 ethyl alcohol 3종이 검출되었다. Ethyl alcohol을 제외한 검 출 성분들은 극소량으로 초기 알코올 함량에 따른 큰 차이 가 없었고, ethyl alcohol은 364 581 ppm으로 나타났다. 
Table 4. Changes in organic acid of the grape vinegar fermentation by initial alcohol content and fermentation stage

\begin{tabular}{|c|c|c|c|c|c|c|}
\hline \multirow{2}{*}{ Fermentation stage ${ }^{1)}$} & \multirow{2}{*}{$\begin{array}{c}\text { Initial } \\
\text { alcohol content } \\
(\%)\end{array}$} & \multicolumn{5}{|c|}{ Organic acid (mg\%) } \\
\hline & & Oxalic acid & Tartaric acid & Malic acid & Acetic acid & Citric acid \\
\hline \multirow{4}{*}{$\mathrm{W}$} & 6 & $15.9 \pm 0.8^{20 b 3)}$ & $132.1 \pm 1.6^{\mathrm{c}}$ & $173.3 \pm 3.5^{\mathrm{d}}$ & $\mathrm{ND}^{4)}$ & $171.3 \pm 9.4^{\mathrm{NS}}$ \\
\hline & 7 & $17.2 \pm 2.6^{\mathrm{b}}$ & $133.4 \pm 2.0^{c}$ & $194.7 \pm 3.3^{c}$ & $\mathrm{ND}$ & $178.7 \pm 8.4$ \\
\hline & 8 & $33.9 \pm 0.1^{\mathrm{a}}$ & $146.2 \pm 8.3^{b}$ & $223.4 \pm 0.1^{\mathrm{b}}$ & ND & $180.4 \pm 0.4$ \\
\hline & 9 & $33.0 \pm 0.0^{\mathrm{a}}$ & $158.6 \pm 0.6^{\mathrm{a}}$ & $235.1 \pm 0.6^{\mathrm{a}}$ & $\mathrm{ND}$ & $185.5 \pm 1.1$ \\
\hline \multirow{4}{*}{ IAAF } & 6 & $24.3 \pm 0.0^{\mathrm{d}}$ & $132.2 \pm 5.1^{\mathrm{d}}$ & $167.2 \pm 5.5^{\mathrm{c}}$ & ND & $152.1 \pm 1.7^{\mathrm{NS}}$ \\
\hline & 7 & $27.1 \pm 0.2^{\mathrm{c}}$ & $121.1 \pm 0.6^{\mathrm{c}}$ & $146.8 \pm 1.1^{\mathrm{b}}$ & $\mathrm{ND}$ & $158.9 \pm 1.2$ \\
\hline & 8 & $31.8 \pm 0.1^{\mathrm{b}}$ & $144.1 \pm 1.4^{b}$ & $203.2 \pm 0.4^{\mathrm{a}}$ & $\mathrm{ND}$ & $163.2 \pm 8.6$ \\
\hline & 9 & $34.3 \pm 1.3^{\mathrm{a}}$ & $159.6 \pm 6.0^{\mathrm{a}}$ & $212.9 \pm 12.7^{\mathrm{a}}$ & $\mathrm{ND}$ & $154.1 \pm 39.2$ \\
\hline \multirow{4}{*}{$\begin{array}{c}\text { 1st stage } \\
\mathrm{AAF}\end{array}$} & 6 & $40.8 \pm 0.8^{\mathrm{d}}$ & $149.2 \pm 13.8^{\mathrm{NS}}$ & $147.2 \pm 9.5^{\mathrm{c}}$ & $5,539.4 \pm 10.0^{c}$ & $114.7 \pm 4.0^{\mathrm{NS}}$ \\
\hline & 7 & $54.0 \pm 1.1^{\mathrm{c}}$ & $155.6 \pm 10.3$ & $129.7 \pm 6.5^{\mathrm{d}}$ & $5,596.3 \pm 7.8^{\mathrm{b}}$ & $120.5 \pm 10.2$ \\
\hline & 8 & $55.9 \pm 0.2^{\mathrm{b}}$ & $146.6 \pm 0.5$ & $166.7 \pm 2.2^{b}$ & $7,649.3 \pm 26.0^{\mathrm{a}}$ & $111.0 \pm 15.5$ \\
\hline & 9 & $59.4 \pm 0.2^{\mathrm{a}}$ & $154.5 \pm 16.5$ & $182.5 \pm 0.4^{\mathrm{a}}$ & $4,837.3 \pm 25.7^{\mathrm{d}}$ & $123.8 \pm 8.8$ \\
\hline \multirow{4}{*}{$\begin{array}{l}\text { 2nd stage } \\
\mathrm{AAF}\end{array}$} & 6 & $51.3 \pm 0.7^{\mathrm{c}}$ & $228.0 \pm 9.4^{\mathrm{NS}}$ & $317.4 \pm 6.9^{\text {NS }}$ & $10,351.4 \pm 15.8^{\mathrm{a}}$ & $311.7 \pm 7.6^{\mathrm{NS}}$ \\
\hline & 7 & $67.6 \pm 1.7^{\mathrm{a}}$ & $223.4 \pm 7.9$ & $305.2 \pm 12.5$ & $10,136.2 \pm 19.0^{\mathrm{b}}$ & $287.9 \pm 28.3$ \\
\hline & 8 & $59.4 \pm 0.1^{\mathrm{b}}$ & $227.0 \pm 1.2$ & $308.1 \pm 1.5$ & $10,085.6 \pm 5.0^{c}$ & $279.9 \pm 18.3$ \\
\hline & 9 & - & - & - & - & - \\
\hline
\end{tabular}

${ }^{11} \mathrm{~W}$, grape wine; IAAF, initial acetic acid fermentation broth; 1st AAF, 1st stage acetic acid fermentation broth; 2nd AAF, 2nd stage acetic acid fermentation broth.

${ }^{2)}$ Values are mean $\pm \mathrm{SD}(\mathrm{n}=3)$.

${ }^{3)}$ Means with different superscripts (a-d) in the same column are significantly different $(\mathrm{p}<0.05)$ by Duncan's multiple range test.

${ }^{4} \mathrm{ND}$, not detected; NS, not significantly different.

Table 5. Alcohol component of the grape vinegar production by initial alcohol content

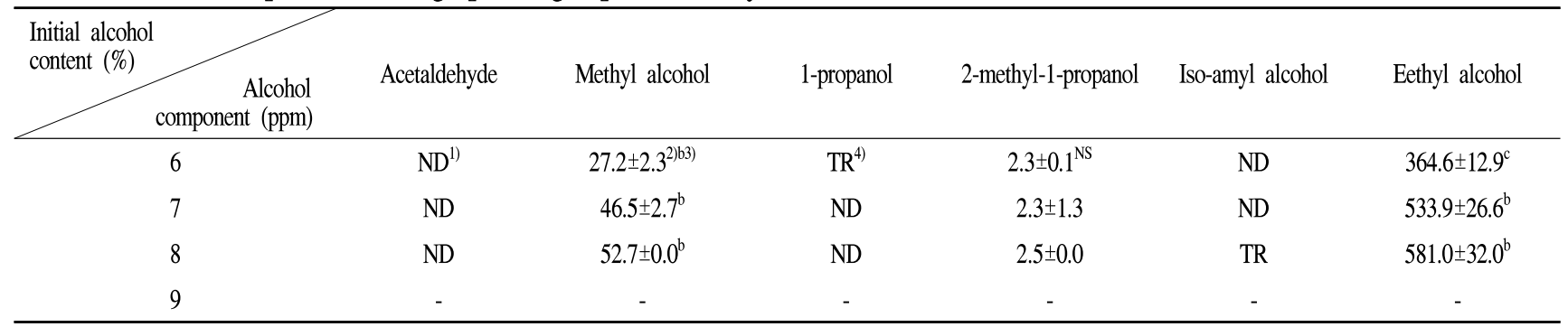

${ }^{1)} \mathrm{ND}$ : not detected.

${ }^{2)}$ Values are mean $\pm \mathrm{SD}(\mathrm{n}=3)$

${ }^{3}$ Means with different superscripts $(a-c)$ in the same column are significantly different $(p<0.05)$ by Duncan's multiple range test.

${ }^{4} \mathrm{TR}$, trace; NS, not significantly different.

\section{요 약}

본 연구에서는 수입에 의존하고 있는 고산도 식초 생산 기술을 대체하고자 포도과즙을 이용하여 적정산도 $10 \%$ 이상의 식초 제조조건 및 품질특성을 조사하였다. 초기 알 코올 함량에 따른 고산도 초산발효에서는 초기 알코올 함량 $6 \%$ 에서 적정산도 $12 \%$ 의 고산도 식초 제조가 가능하였으 며 초기 알코올 함량이 높을수록 유도기가 길어져 초산수율 이 감소하였다. $\mathrm{pH}$ 는 구간에 따른 큰 차이가 없었고, 당도는
1 단계 초산발효(1st $\mathrm{AAF}$ )까지 초기 알코올 함량에 비례하 여 높게 나타났으나 2단계 초산발효(2nd $\mathrm{AAF}$ )기간 동안에 는 초기 알코올 $6 \%$ 첨가구에서 증가율이 가장 높았다. 고산 도 포도식초의 주요 유기산은 tartaric, malic 및 citric acid가 검출되었으며, 유가식 첨가량 및 초산 발효수율 차이로 인 하여 초기 알코올 함량이 낮을수록 높게 검출되었다. 미량 알코올 중 ethyl alcohol을 제외한 성분은 극소량으로 검출 되어 초기 알코올 함량에 따른 큰 차이가 없었고, ethyl alcohol은 364 581 ppm으로 나타났다. 이상의 결과, 포도 
알코올 발효액(초기 알코올 함량 $6 \%$ )를 이용하여 일체의 영양원을 첨가하지 않고 총산도 $12 \%$ 의 고산도 식초 제조가 가능하였다. 그러나 산업적으로 활용하기 위해서는 초산수 율 향상 및 유가식 첨가에 의한 발효기간 단축에 관한 보완 연구가 요구되었다.

\section{감사의 글}

본 연구는 농촌진흥청 공동연구사업(과제번호 : PJ008488022014)의 지원에 의한 연구결과의 일부로 이에 감사드립니다.

\section{References}

1. Chang SW, Kim HJ, Song JH, Lee KY, Kim IH, Rho YT (2011) Determination of several phenolic compounds in cultivars of grape in Korea. Korean J Food Preserv, $18,328-334$

2. Kim MH, Kwak HJ, Yoo BH, Kim DJ, Youn SJ (2013) Quality characteristics and antioxidant effects of grape juice obtained with different extraction methods. Korean J Food Preserv, 20, 784-790

3. Ko JY (2011) Wine communication. Sekyungsa, Seoul, Korea, p 103

4. Kim SB, Park JK, Kim TG, Lim DH, Lee HJ, Ki KS, Son JK, Kim HS, Kim SC, Kweon EK (2011) Effect of dietary grape by-product on milk yield, milk composition and bleed metabolites of dairy cows. J Agri Life Sci, 45, 135-140

5. Park SJ, Lee HY, Oh DH (2003) Free radical scavenging effect of seed and skin extracts from Campbell Early grape(Vitis labruscana B.). J Korean Soc Food Sci Nutr, 32, $115-118$

6. Alkhalaf M (2007) Resveratrol-induced apoptosis is associated with activation of $\mathrm{p} 53$ and inhibition of protein translation in T47D human breast cancer cells. Pharmacol, 80, 134-143

7. Mellors A, Tappel AL (1996) The inhibition of mitochondrial peroxidation by ubiquinone and ubiquinol. J Biol Chem, 241, 4353-4356

8. Heo JC, Woo SU, Kweon MA, Kim BB, Lee SH, Lee JM, Choi JU, Chung SK, Lee SH (2007) Analysis of immunomodulating activities in methanol extracts from several kinds of grapes. Korean J Food Preserv, 14, $419-424$
9. Kim MA, Son HU, Yoon EK, Choi YH, Lee SH (2012) Comparison of anti-diabetic activities by extracts of grape cultivar. Korean J Food Preserv, 19, 400-405

10. Casale M, Sáiz AMJ, González SJM, Pizarro C, Forina $M$ (2006) Study of the aging and oxidation processes of vinegar samples from different origins during storage by near-infrared spectroscopy. Analy Chim Acta, 557, 360-366

11. Chol EH, Kim DS, Choi SK, Park KB (2013) Optimization and quality characteristics of balsamic vinegar jelly with various gelling agents. Korean $\mathbf{J}$ Culinary Research, 19, 151-163

12. Woo SM, Jo YJ, Lee SW, Kwon JH, Yeo SH, Jeong YJ (2012) Quality comparison of static-culture and commercial brown rice vinegars. Korean J Food Preserv, 19, 301-307

13. Lee YC, Lee JH (2000) A manufacturing process of high-strength vinegar. Food Indus Nutr, 5, 13-17

14. Park KS, Chang DS, Cho HR, Park UY (1994) Iinvestigation of the cultural characteristics of high concentration ethanol resistant Acetobacter sp. J Korean Soc Food Nutr, 23, 666-670

15. Park MH, Lyu DK, Ryu CH (2002) Characteristics of high acidity producing acetic acid bacteria isolated from industrial vinegar fermentation. J Korean Soc Food Sci Nutr, 31, 394-398

16. Lee YC, Lee YG, Kim HC, Park KB, Yoo YJ, Ahn PU, Choi CU, Son SH (1992) Production high acetic acid vinegar using two stage fermentation. Korean $\mathrm{J}$ Microbiol Biotechnol, 20, 663-667

17. Lee YC, Park MS, Kim HC, Park KB, Yoo YJ, Ahn IK, Son SH (1993) Production of high acetic acid vinegar by single stage fed-batch culture. Korean J Microbiol Biotechnol, 21, 511-512

18. Park HS (2010) Characteristics of peach wine with different commercial yeast strains. J East Asian Soc Dietary Life, 20, 531-535

19. Sung NH, Woo SM, Kwon JH, Yeo SH, Jeong YJ (2014) Quality characteristics of high acidity apple vinegar manufactured using two stage fermentation. J Korean Soc Food Sci Nutr, 43, 877-883

20. Park WM, Park HG, Rhee SJ, Lee CH, Yoon KE (2002) Suitability of domestic grape, cultivar Campbell's Early, for production of red wine. Korean J Food Sci Technol, 34, 590-596

21. Moon YJ, Lee MS, Sung CK (2004) The fermentation properties of red wine using active dry yeast strains. 
Korean J Food Nutr, 17, 450-457

22. Iverson $\mathbf{J}$ (2000) Home wine making step by step : a guide to fermenting wine grapes, 3rd ed. Stonemark Publishing Co., Medford, Oregon, USA, p 67-78

23. Kim YD, Kang SH, Kang SG (1996) Studies on the acetic acid fermentation using maesil juice. J Korean Soc Food Sci Nutr, 25, 695-700

24. Kim GR, Yoon SR, Lee JH, Yeo SH, Jeong YJ, Yoon KY, Kwon JH (2010) Physicochemical properties of and volatile components in commercial fruit vinegars. Korean J Food Preserv, 17, 616-624
25. Kim HS, Yook C, Sung CK, Kim HJ, Lee SH, Kim YH, Lee KY, Lee JW (2008) Characteristics of red wines fermented with different strains of dry. Korean J Food Preserv, 15, 306-310

26. Bae IY, Lee KY, Shin MS, Lee HG (2004) Development of red wine using Monascus anka. Korean J Food Sci Technol, 36, 744-748

27. Kwon SH, Jeong EJ, Lee GD, Jeong YJ (2000) Preparation method of fruit winegars by two stage fermentation and beverages including vinegar. Food Indus Nutr, 5, 18-24 